\title{
A GERAÇÃO MILLENIAL, O EFEITO GRETA E A DEFESA DO CLIMA
}

\section{MILLENIAL GENERATION, GRETA EFFECT AND CLIMATE DEFENSE}

WAGNER ANDRE JOHANSSON

Mestrando do Centro Universitário Curitiba - UNICURITIBA. Curitiba - PR. E-mail: wagner.advocacia@gmail.com

\section{RESUMO}

O artigo parte do questionamento sobre as consequências da saída do Acordo de Paris recentemente noticiada pela imprensa nacional. Como a Europa trata da questão ambiental? Quem são os millenials e de que se tratam as Sextafeiras pelo futuro? - Sendo certo que devemos nos preocupar em proteger o meio ambiente para as gerações futuras, conforme preconizado em nosso ordenamento pátrio, também é certo que surge entre a juventude a chamada geração millenials, que não espera por nossas iniciativas. Por todo o planeta, este movimento que se declara apartidário tem uma única reivindicação: pede aos governos que cumpram com o que se comprometeram no Acordo de Paris. Este pacto, que data de 2015 e começará a ser efetivo a partir de 2020, tem metas - que o irreversível aumento da temperatura permaneça dentro de limites controláveis, entre 1,5 e 2 graus - e define como alcançá-las - por meio da eliminação de gases de efeito estufa da economia mundial. Na ausência de sanções ou outros instrumentos que obriguem os países a cumprirem o acordo, a pressão social é essencial para pressionar os Governos a reduzirem as emissões com intensidade suficiente. Estão sozinhos desde já lutando pela proteção ambiental. Pela coincidência dos anos em que nasceram, os millenials são obrigados a lidar com condições muito duras de vida. $A$ 


\section{Personalidade Acadêmica Homenageada:}

\section{Augustus B. Cochran III (Agnes Scott College)}

crise financeira global os atingiu em cheio, dificultou sua entrada no mercado de trabalho e os fez sofrer reveses nas principais conquistas da vida. Em primeiro lugar, a enorme massa que simplesmente se uniu, impulsionada pela profunda seriedade e determinação da jovem sueca Greta Thunberg, que em meados do ano passado decidiu se sentar em frente ao prédio do Parlamento em Estocolmo em vez de ir à escola. É claro que o apelo de algo proibido desempenha um papel, assim como a perspectiva de algumas horas empolgantes fora dos muros da escola. Mas reduzir o movimento Fridays for Future a isso seria algo bastante arrogante. Luisa Neubauer foi uma das iniciadoras das "sextas-feiras para o futuro" na Alemanha. A mídia considera a estudante de geografia de 22 anos como a Greta Thunberg alemã. Neubauer conheceu Thunberg na conferência sobre o clima em Katowice. "Eu pensei: temos que mudar muita coisa e rapidamente fazer muito alarde", afirmou Neubauer em entrevista. "Nossos protestos geram uma pressão pública, que chama todos os tomadores de decisão à responsabilidade e aumenta a necessidade de agir." Portanto, nos partidos, organizações e associações que têm atuado na luta contra as mudanças climáticas a irrupção do movimento estudantil é festejada como um fator de pressão nos governantes. O movimento que nasceu na Europa, já ganha espaço em nosso território. Um grande sinal vermelho se acendeu quando os EUA deixaram o acordo e o atual presidente eleito anunciou que pretendia deixar o pacto por entender que sua internalização atacaria a soberania nacional ao dificultar o empreendedorismo. A atividade empresaria deve considerar a defesa do meio ambiente sob pena de ser responsabilizada pelos danos causados. O pesquisador de protestos Sebastian Koos, de Konstanz, também acredita que as "Sextas-Feiras para o Futuro" tem o potencial de se tornar um movimento de longo prazo. Ele estava se referindo ao "efeito Greta": segundo Koos, os jovens viram que podem provocar mudanças. Por conclusão, a geração do futuro luta para ter futuro e não espera acontecer e o faz com pressa e propriedade. Só por isso merece ao menos ser ouvida.

PALAVRAS-CHAVE: Meio Ambiente; Geração Millenial; Friday For Future. 
Personalidade Acadêmica Homenageada:

Augustus B. Cochran III (Agnes Scott College)

\section{REFERÊNCIAS}

AMADEU, Maria Simone Utida Dos Santos [et all]. Manual de documentos científicos de acordo com as normas da ABNT. Curitiba: Ed UFPR, 2015.

BURACK, Cristina. Opinião: Millenials, uma geração incompreendida. Disponível em:<https://www.dw.com/pt-br/opini\%C3\%A3o-millenials-

umagera\%C3\%A7\%C3\%A3o-incompreendida/a-47792953?maca=bra-Red-

WhatsApp>. Acesso em 09.04.2019

CARVALHO,Cleida. Salles diz que Brasil permancece no Acordo de Paris. .Disponível em:<https://oglobo.globo.com/brasil/salles-diz-que-brasil-permanece-noacordo-de-paris-23371858 >. Acesso em 03/05/2019

THURAU, Jens. Opinião: É hora de levar estudantes em greve pelo clima a sério. Disponível em: <https://www.dw.com/pt-br/opini\%C3\%A3o-\%C3\%A9-hora-de-levarestudantes-em-greve-pelo-clima-a-s\%C3\%A9rio/a-47947377?maca=bra-RedWhatsApp>. Acesso em 09.04.2019 